\title{
Design of Autofocus Microscope with Histogram Method for Tuberculosis Bacteria Observation
}

\author{
Mohammad Kholil ${ }^{1}$, Riries Rulaningtyas ${ }^{1, \text { a) }}$, Winarno ${ }^{1}$ \\ ${ }^{1}$ Department of Physics, Faculty of Science and Technology, Universitas Airlangga

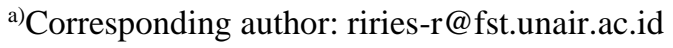

\begin{abstract}
This research was conducted to design an autofocus microscope with a histogram method that can observe Tuberculosis (TB) bacteria. The bacteria observed were preparations or phlegm preparations which had been stained with Ziehl Neelsen. The microscope is designed to be equipped with a program to control the focus motor that moves the microscope tube and the program to digitally display the image and histogram of TB bacteria. Histograms are analyzed based on intensity values spread between 0-255 and the entropy value is sought. The measurement results that have been carried out as many as 20 times the field of view of the TB bacteria show that the most focused areas have the highest entropy value with an accuracy level ranging from $81.90476 \%$ to $100 \%$ at 1000 times the magnification.
\end{abstract}

\section{INTRODUCTION}

Tuberculosis (TB) a chronic disease that becomes a big health problem in the world, including Indonesia. WHO stated that TB nowadays becomes a global threat. It is expected that 1.9 billion or one third of world population were infected by this disease. Each year 9 million of new TB sufferers were detected with a mortality value of 3 million people. In the developing country, the mortality rate reached $25 \%$ of all the cases that actually could be handled related with the finding of TB bacteria. The death mostly was caused by the failure in the detection of the case and treatment [3].

The failure of treatment often occurred due to the limit of the device that could diagnose, detect, or identify the disease. A bacteria-based disease is identified by observing the cell structure of the cause. In performing that process, we could not identify it without the help of device, such as microscope [5].

Microscope is an optical device consisting of one or more lenses that produce a magnified figure from a thing that is placed in the focal area of that lens. In supporting the medical device development, microscope is one of optical instruments that is used to observe small-scale and naked-eye invisible things, such as cells and bacteria. In a simple way, microscope is consisted of objective lens which is close to the object and ocular lens which is close to the observer. To catch the shadow of the observed thing, the thing is placed in front of the objective lens. Then, the macrometer and micrometer are rotated until the shadow of the object is clear. Besides that, a microscope also need a source of light that is used to illuminate the object to be observed. It aims to observe small objects from living or dead things, such as sample preparat [5].

Most of the microscopes used in Indonesia is a conventional or non-digital microscope [1]. The user of the conventional microscope needs to have specific skills to determine the combination of the les magnification and focal control so that the result of the observation was clear and sharp. This job is not easy for the untrained and sight deficiency user [6]. One of the improvement to increase the value and usability of the conventional microscope is by doing modification to be a digital microscope. Autofocus is a basic technology to be applied in the biology and biomedical field automatically. However, this method is not fully developed in Indonesia [7]. Autofocus has an important role in the cell calculation because a focus cell figure is needed before the calculation process is performed [2]. Nowadays, a lot of medical and biological procedure need cell calculation as a part of diagnostic devices [4].

To obtain a fast diagnosis result, a system of microscope need more added values to reduce the workload of the officer that perform it manually, especially in finding the focal point. The conventional microscope is related 
with the subjectivity of the user so that the possibility to have a different diagnosis is present. Besides that, the fatigue factor also cause problem in several case diagnoses. Thus, to replace that condition, a system is needed to perform that activity without the presence of subjectivity and fatigue. The proposed method in this study is by modifying the microscope with addition of camera to replace the eye of observer, focal driver with motor DC stepper nemma 17 bipolar with four cables as current transfer. This microscope is connected to the laptop as a visual and control device [6].

\section{RESEARCH METHODOLOGY}

This study was performed in three steps, which were mechanical, electronic and software designs. The tools and materials used in this study were laptop, microscope that has been modified, camera, additional tools, and software to make and fill the microcontroller. The design of the system was depicted in Figure 1.

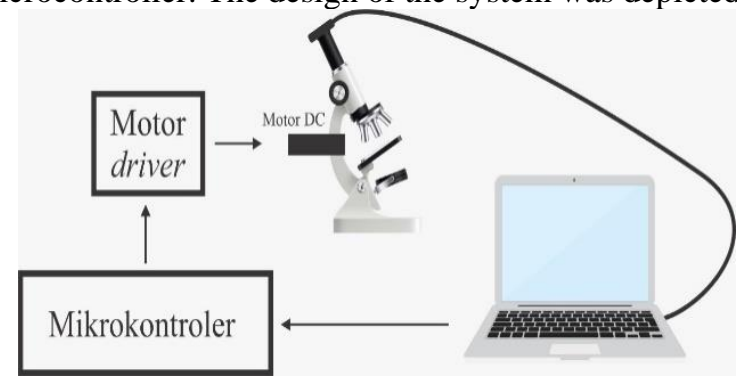

FIGURE 1. The design of physical construction of autofocus microscope

In the early step, the conventional microscope was modified by adding a camera as a media to capture the preparate figure. The modification was also added to drive the focus of the microscope by connecting it to motor stepper. The driving of the motor stepper was performed by PC through the controller box that hada serial communication modul and motor stepper driver.

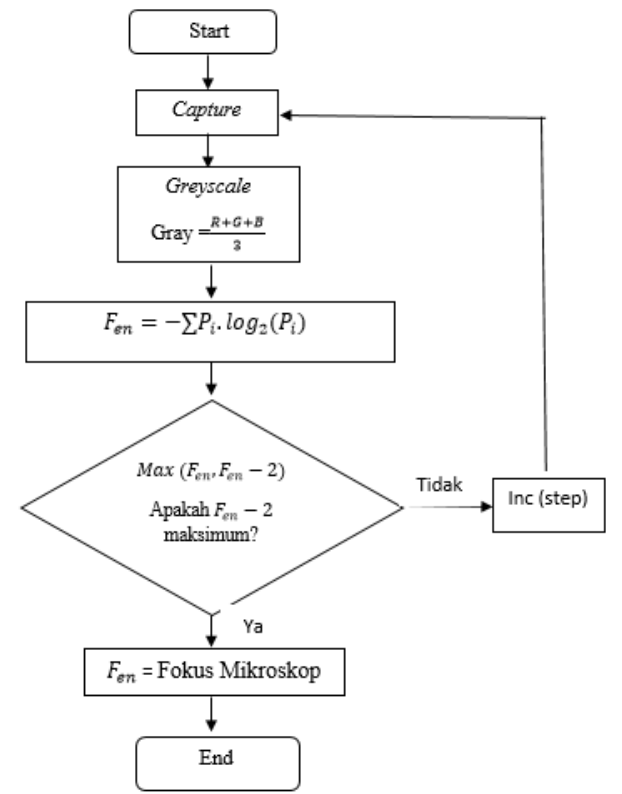

FIGURE 2. The flowchart of focus search of microscope

The method to determine the focus point of the microscope was based on the entropy calculation $\left(\mathrm{F}_{\mathrm{en}}\right)$ in each figure that was produced by the camera. The calculation of the entropy was performed by using Equation 1 .

$F_{\text {entropy }}=-\sum P_{i} \cdot \log _{2}\left(P_{i}\right)$

value of $P_{i}$ is the summation of intensity frequency $h_{i}$ and divided with the image size Hight $x$ Widht. The flowchart of the focus search program in the microscope was shown in Figure 2. The step in finding the focus through autofocus program were listed as follow.

1. Placing the preparate in the object stage in microscope.

2. Controlling the illumination until the figure is clear enough through the camera. 
3. Ensuring the position of the objective lens in an adequate distance above the preparate.

4. Choosing the menu of automatic focus search in the software

5. Finding the focus of the microscope is finished together with the pop up menu in the software.

The data analysis was performed by comparing the result of finding the focus by the user and the computer (autofocus program). In this part, the user determined the focus point of the microscope manually and then calculate the entropy. By using the same object, the program would determine the focus point of the microscope. The entropy of both approaches was compared and analyzed by using paired T Test. If the result of that test is no significant difference between the focus search of the microscope by the user and the computer, so it could be concluded that the autofocus program is successful in replacing the user in finding the focus point of the microscope. This conclusion is applicable in vise versa. You can edit or delete the content provided in this template and replace it with the text and figures of your article. Please be sure you do not accidentally leave any of this text as part of your paper!

\section{RESULT AND DISCUSSION}

The conventional light microscope was modified by adding a camera in the microscope as a media to capture the image. The camera used in this study had a magnification of 12. The connection between the camera and PC was using USB port. The PC used in this study was a laptop with a specification of AMD A8 processor, $4 \mathrm{GHz}$ RAM and Windows 10 Operating Systems. The result of the digital microscope design was shown in Figure 3a.

The focus driver part of the microscope was connected to the stepper motor. The cycle of the stepper motor was controlled by using a driver motor module A4988 that was connected to Arduino microcontroller module. The communication between the microcontroller and PC was by using USB port. The result of the controller design was shown in Figure $3 b$.

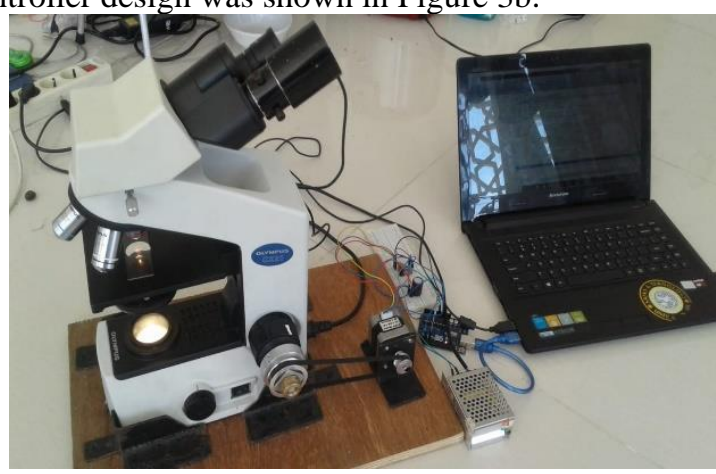

(a)

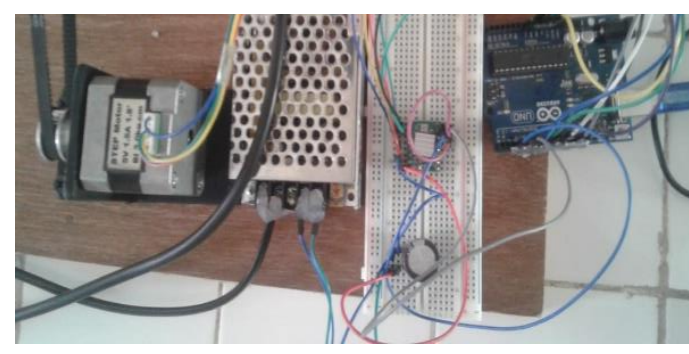

(b)

FIGURE 3. (a) The design of the autofocus microscope and (b) the design of its controller

The software used in this study was divided into two parts, which were the controller software of the microcontroller and the software for user interface (PC display). The controller software for microcontroller has a role as a media to write the code that would be inserted to the microcontroller, compiler and downloader. This software used Arduino IDE 1.5.6r2 version with programming language of $\mathrm{C}++$. The user interface of Arduino 1.5.6r2 was shown in Figure 4. n C++. User interface Arduino versi 1.5.6r2. 


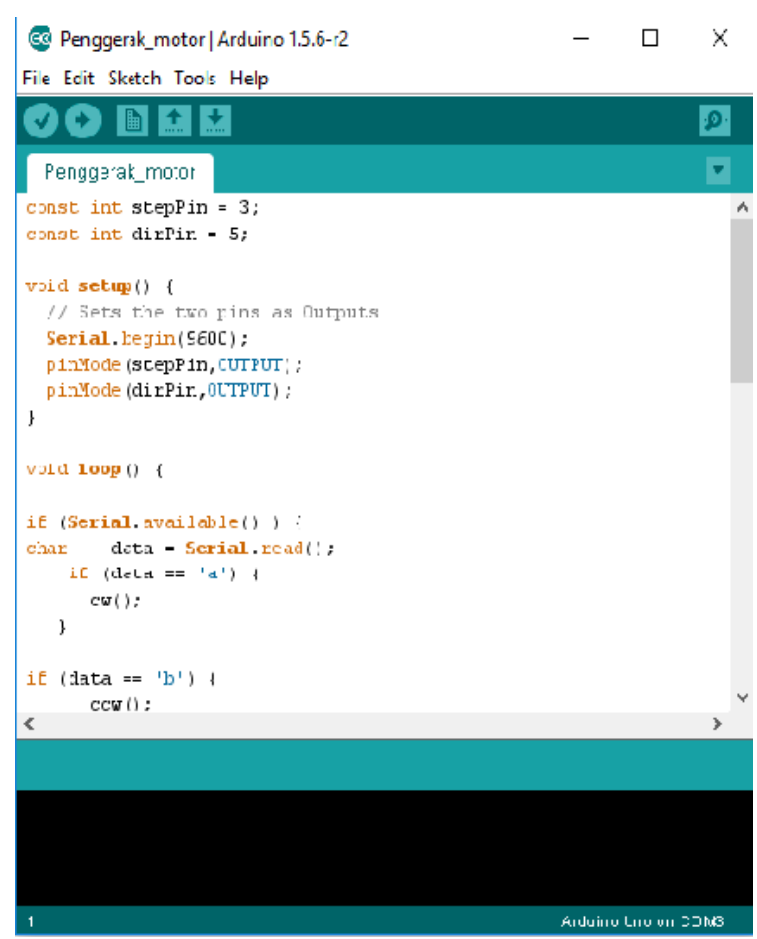

FIGURE 4. The User interface Arduino 1.5.6r2 version

The software in the PC had a role as a user interface to utilize the digital microscope. This software also has a function as image processing to calculate the entropy. The result of the software design was shown in Figure 5. The entropy data from the focus point search process by user and computer was analysed in this step by using the same parameters such as the object illumination, field of view, and lens magnification shown in Figure 6 and 7. The result was shown in Table 1.

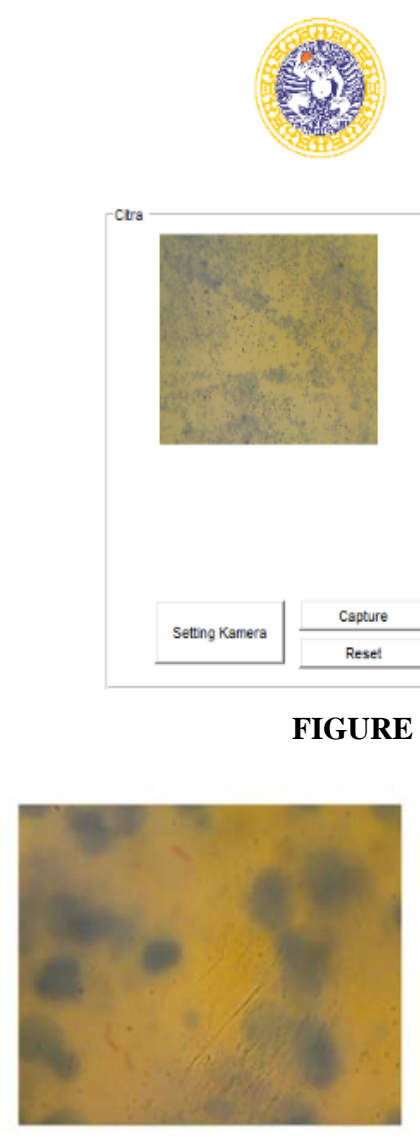

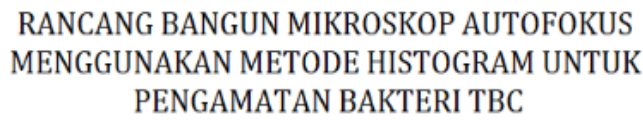

PENGAMATAN BAKTERI TBC
OLEH :

Mohammad Kholil

081411331043

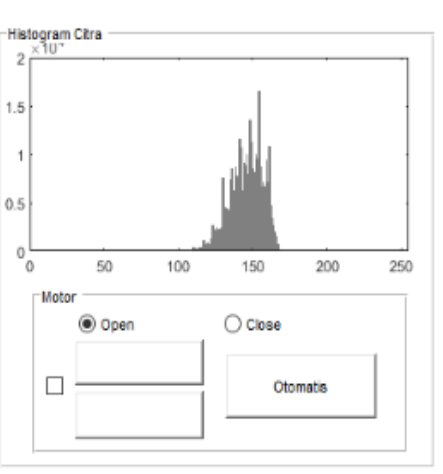

IGURE 5. User interface of the image processing of autofocus program

(a)

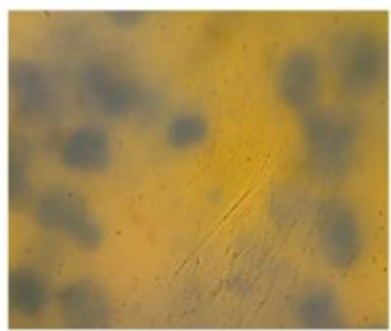

(b)

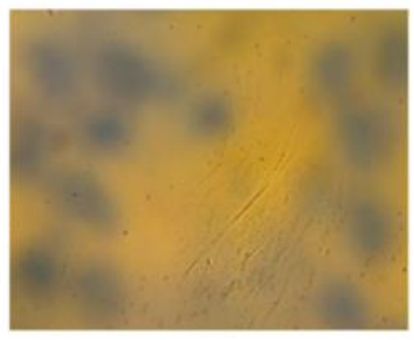

(c) 
FIGURE 6. (a) A focus image, (b) A semi-focus image, and (c) A blurry image

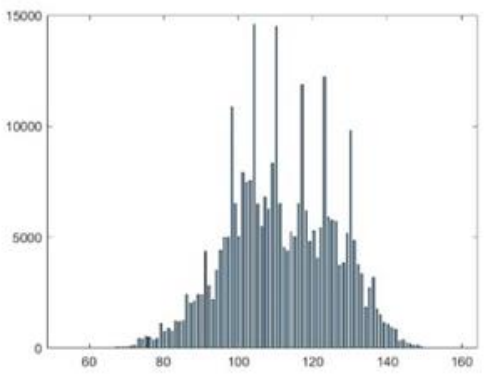

(a)

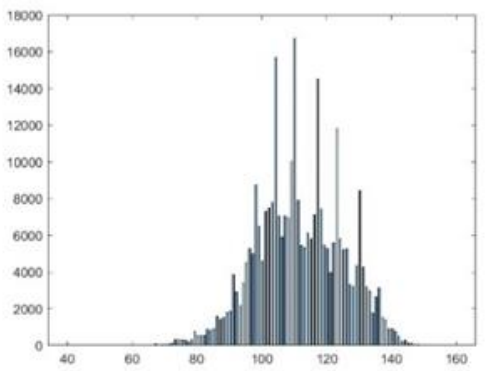

(b)

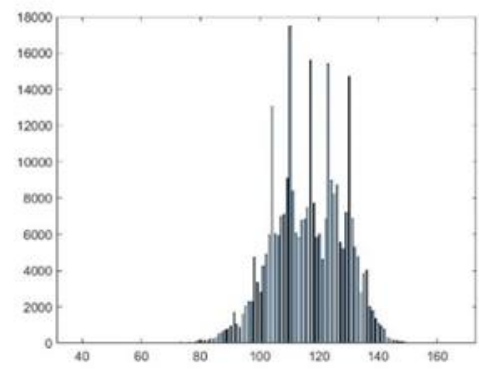

(c)

FIGURE 7. (a) Histogram of focus image, (b) Histogram of semi-focus image and (c) Histogram of blurry image

TABLE 1. The Entropy Data of Image Performed by The User and Computer

\begin{tabular}{|c|c|c|}
\hline \multirow[t]{2}{*}{ nth Data } & \multicolumn{2}{|c|}{$F_{\text {entropy }}$} \\
\hline & User & Computer \\
\hline 1 & 5,52 & 5,57 \\
\hline 2 & 5,66 & 5,66 \\
\hline 3 & 5,40 & 5,50 \\
\hline 4 & 5,68 & 5,52 \\
\hline 5 & 5.76 & 5,80 \\
\hline 6 & 5,62 & 5,70 \\
\hline 7 & 5,63 & 5,67 \\
\hline 8 & 5,60 & 5,48 \\
\hline 9 & 5,73 & 5,70 \\
\hline 10 & 5,50 & 5,35 \\
\hline 11 & 6,30 & 5,16 \\
\hline 12 & 5,87 & 5,77 \\
\hline 13 & 5,61 & 5,81 \\
\hline 14 & 5,81 & 5,25 \\
\hline 15 & 5,79 & 5,63 \\
\hline 16 & 5,75 & 5,77 \\
\hline 17 & 5,77 & 5,68 \\
\hline 18 & 5,78 & 5,77 \\
\hline 19 & 5,76 & 5,78 \\
\hline 20 & 5,82 & 5,68 \\
\hline
\end{tabular}

The data used in this study was sputum sample. The data was captured with a magnification of $1000 \mathrm{X}$. The data was shown in Figure 6. Based on the data in Table 1, the analysis was used paired T Test. Before performing the test by using paired T Test, the data was checked whether it has normal distribution or not. The statistical test used was Lilliefors (Kolmogorov-Smirnov) normality Test.

The hypothesis of normality test:

H0: Data has normal distribution

H1: Data has no normal distrbution

$\alpha=0.05$

The result of normality test was shown in Table 2 .

TABLE 2. The Result of Normality Test

Tests of Normality

\begin{tabular}{|l|r|r|r|r|r|r|}
\hline & \multicolumn{4}{|c|}{ Kolmogorov-Smimov ${ }^{3}$} & \multicolumn{3}{|c|}{ Shapiro-Wilk } \\
\cline { 2 - 7 } & Statistic & \multicolumn{1}{|c|}{ df } & \multicolumn{1}{c|}{ Sig. } & Statistic & \multicolumn{1}{c|}{ df } & \multicolumn{1}{c|}{ Sig. } \\
\hline Pengamat &, 179 & 20 &, 093 &, 868 & 20 &, 011 \\
Komputer &, 201 & 20 &, 033 &, 869 & 20 &, 011 \\
\hline
\end{tabular}

a. Lilliefors Significance Correction 
Based on the result of normality test, the data obtained by the user had p-value of 0.011 and by the computer was 0.011 . Those values were more than 0.05 . Thus, it could be said that the data has normal distribution and paired T Test could be performed.

The hypothesis of checking the significant difference of focus search:
$H 0: \mu 1-\mu 0=0$
$H 1: \mu 1-\mu 0 \neq 0$
$\alpha: 0.05$

TABLE 3. The Result of Paired T Test of the user and computer data in focus search.

Paired Samples Test

\begin{tabular}{|c|c|c|c|c|c|c|c|c|c|}
\hline & & \multicolumn{5}{|c|}{ Paired Differences } & \multirow[t]{3}{*}{$t$} & \multirow[t]{3}{*}{$d f$} & \multirow[t]{3}{*}{ Sig. (2-tailed) } \\
\hline & & \multirow[t]{2}{*}{ Mean } & \multirow[t]{2}{*}{ Std. Deviation } & \multirow[t]{2}{*}{ Std. Error Mean } & \multicolumn{2}{|c|}{$\begin{array}{c}95 \% \text { Confidence Interval of the } \\
\text { Difference }\end{array}$} & & & \\
\hline & & & & & Lower & Upper & & & \\
\hline Pair 1 & Pengamat - Komputer &, 10100 &, 28820 &, 06444 &,- 03388 &, 23588 & 1,567 & 19 &, 134 \\
\hline
\end{tabular}

Based on the result of paired T Test in Table 3, it was shown that the p-value was 0.134 which was more than 0.05 and meant there was no significant difference and $\mathrm{H} 0$ was accepted. This result indicate of that the distance entropy value between the user and computer was zero. In conclusion, there is no difference in focus search performed by the microscope user and computer so that the proposed autofocus program in this study could replace the role of human in focus search in the microscope.

\section{CONCLUSION}

Based on the result of this study, it could be concluded that the method to determine the focus of microscope by using entropy of the histogram was successful and it could replace the position of the user for that job.

\section{REFERENCE}

1. Hartati S., Harjoko A., Supardi T. W., 2011, The Digital Microscope and Its Image Processing Utility, Telkomnika 9, 657-574.

2. Mazalan, N. H. Mahmood, 2013. Automated Red Blood Cells Counting in Peripheral Blood Smear Image Using Circular Hough Transform. International conference on Artificial Intelligence, Modelling and Simulation. 320-324.

3. Ratnasari, N,Y., 2012. Hubungan Dukungan Sosial Dengan Kualitas Hidup Pada Penderita Tuberkulosis Paru (Tb Paru) Di Balai Pengobatan Penyakit Paru (Bp4) Yogyakarta Unit Minggiran. Jurnal Tuberkulosis Indonesia. 8: 7-11.

4. Razak. 2013. Automated Platelet Counter Based on the Modified Hough Transform. Journal of Medical Imaging Health Information. 3: 543-546.

5. Schlegel, H.G. \& K. Schmidt. (1994). Mikrobiologi Umum. Gadjah Mada University Press. Yogyakarta

6. Winarno, W dkk. 2016. Desain Sistem Autofocus Berbasis Normalized Variance untuk Pencari Fokus Otomatis Mikroskop. Conference Paper 2016.

7. Yu Sun, Duthaler S, Nelson BJ, 2005, Autofocusing Algorithm Selection in Computer Microscopy, IEEE. 